\title{
31. 当科に打けるヒステロスコープの成績
}

\author{
(荘病院産婦人科) \\ 長 崎淳一・檜 垣 敬 二・瀬尾道次 \\ 荘 \\ 進
}

近年内視鏡の進歩により直視下に於ける子宮内 腔の異常の検索及び治療が盛んに行われて括りま す．当院に掠さむても昭和 63 年 1 月よりヒス テロスコープを使用した検査, 治療を開始致しま した。主な症例は習慣流産 8 例, 不正性器出血 13 例, HSG に於ける子宮内腔異常 9 例の他畉管角よ り AIH を行う Hysteroscopic insemination into tube (HIT)等であります。器械はフジノン HYS-F 及 びオリンパス HYS-PX，外来にて無麻酔下にて施 行しております。症例成績では, 習慣流産に於い ては明らかな所見は認めませんでした。 不正性器 出血例では内膜ポリープ及び粘膜下筋腫をそれぞ れ 1 例ずつ認めました。 子宮内腔異常例では内腔 癒着を 2 例認めました。 又当院に於いては不妊症 患者の多いことより HIT を積極的に施行してゆ きたいと考えています，現在は AIHを 10 回以上 行っても妊娠しない症例や, oligospermia に対し て施行して拉ります．施行時期は通常の AIH と 同様に基礎体温，頝管粘膜，経胵スキャンによる Follicle にて決定しています. 精子はパーコール洗 浄, $500 \times 10^{4} / \mathrm{ml}$ に調整します。挿入カテーテル
はアーガイルメディカルカテーテル外径 $0.8 \mathrm{~mm}$ を使用し卵管角より約 $1.5 \mathrm{~cm}$ 挿入します。卵管 角確認困難時には生食にて内圧を加光視野を確保

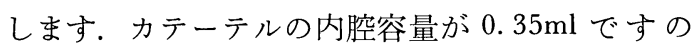
で $0.05 \mathrm{ml}$ を加えた $0.4 \mathrm{ml}$ を注入精子量としまし た. 処置後 $2 \sim 3$ 日の出血例を除いて他の副作用 はございませんでした，又カテテール挿入による 卵管間質部の状態に対しては月経周期を有する 43 才の摘出標本に拉いて損傷をほとんど認めません でした。長年の不妊症や oligospermia に対しIVFET PIFT は確立された方法でありますが患者 サイドの負担も大であります．残念ながら当院で の HIT による妊娠例婂ございませんが，卵管疎 通性が有るのにもかかわらず HSG で卵管閉鎖を 示す場合が多々あります，何らかの原因でAIHを 行っても精子が卯管に移行出来ないケースもある かと思われます。その椂なケースでは直接卵管内 に精子を注入することも意味があるのではないか と考え, 外来で簡便に施行可能であることと合わ せ今後も積極的に症例を重ねてゆさたいと考えて おります。 